$\begin{array}{cccccccc}p_{\mathrm{mm}} & 733.5 & 447.75 & 574.2 & 634.05 & 809.9 & 921.5 & \\ 1 & \times & & \times & & \times & \times & 848.56 \\ 2 & \times & & \times & \times & \times & \times & 848.11 \\ 3 & \times & & \times & \times & \times & 848.30 \\ 4 & & \times & \times & \times & \times & & 847.31 \\ 5 & & \times & \times & \times & & \times & 846.11\end{array}$

因に計算の詳細は第一二報にあり（×印は計算に使用のもの）(1)，(2)，(3)の壮均は $848^{\circ} .32^{\circ} \mathrm{C} な り$

第五表及第六表を通覽するに分解獎式中熱力學に適する $(\mathrm{C}),(\mathrm{D}),(\mathrm{G}),(\mathrm{P}),(\mathrm{Q})$ 等は $850^{\circ} \sim 852^{\circ} \mathrm{C}$ 又實 測值に近きもの $(\mathrm{H}),(\mathrm{T})$ 及ラグランヂ補內の計算は $848^{\circ} \sim 850^{\circ} \mathrm{C}$ なり今分解圈賽騟值をジョンストン氏の實 驗に比し正確度 $\pm 2^{\circ} \mathrm{C}$ とすれば本報實驗の $855^{\circ} \sim 856^{\circ} \mathrm{C}$ と合致する事となる

装旨

(1) 檢度せるネルンスト氏ミクロトーションスワーゲ、熱電對及び電位差計を使用 $L \mathrm{Na}_{2} \mathrm{CO}_{3}$, と $\mathrm{F}_{2} \mathrm{O}_{3}$, 混 合物の分解然を測定し $855^{\circ} \mathrm{C}$ を得たり

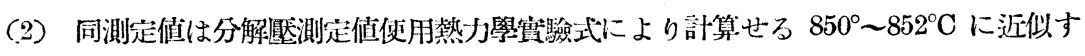

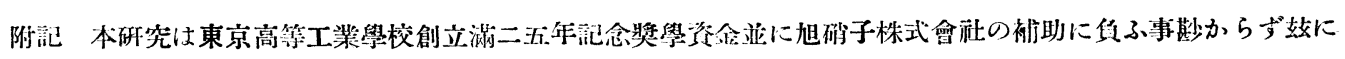
感謝の意え表す

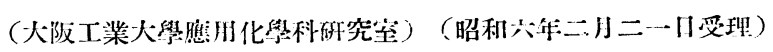

\title{
脂油硬化に於て生するる新化合物に就て(第三報)
}

\section{アル デヒドに就て}

上野 䙘一 - 川峆利一即

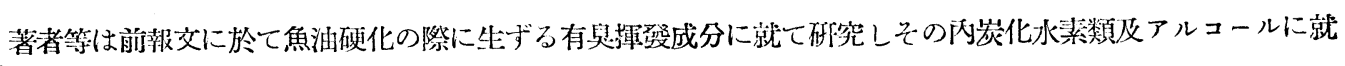

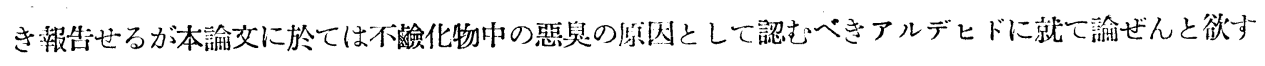

原料揮發性油狀物 $500 \mathrm{~g}$ にェーテル $500 \mathrm{cc}$ を加へて溶液となし之に酸性亞硫酸曹達の飽和溶液 $500 \mathrm{cc}$ を加

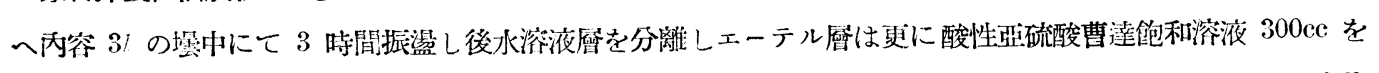

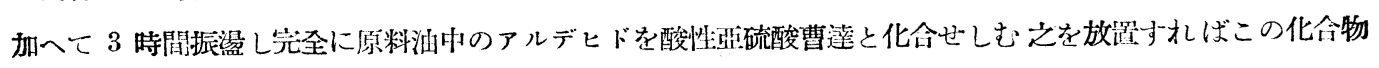
は外見乳状をなしエーテル厤中に㗭垂混濁し透时の水溶液曆と分離す

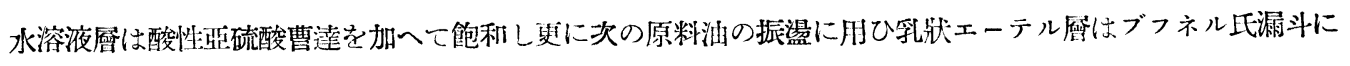
て濾渦し濃き糊狀の白色沈澱を得さり

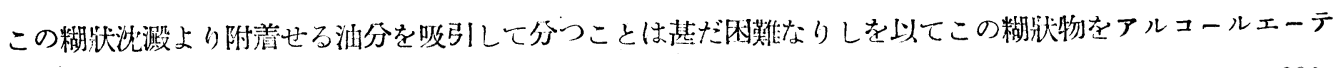

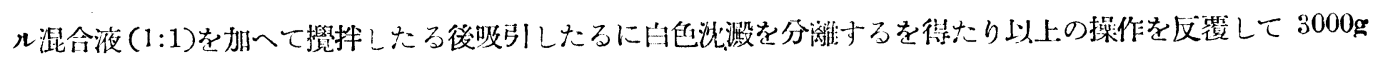

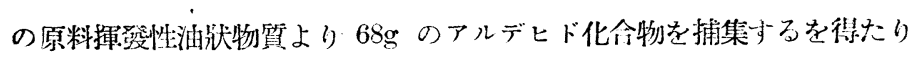

この沈澱は沸騰アルコールには甚だよく溶解し冷却すれば列んど全部を析出すェーテルには溶解せず故に全

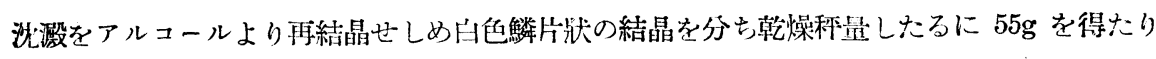

この結晶 $55 \mathrm{~g}$ を $100 \mathrm{~g}$ の溫水を加へて糊哭となし別に $80 \mathrm{~g}$ の結晶炭酸曹澾を濃溶液となして之を加へて分

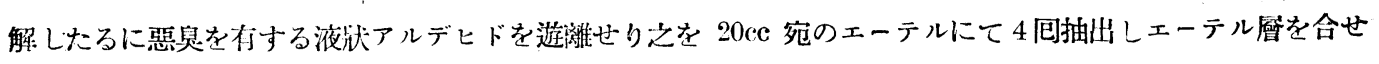




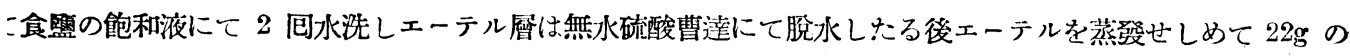
黃色流動性惡臭油狀物を得たり

このアルデヒド $22 \mathrm{~g}$ の中 $4 \mathrm{~g}$ は後述の如く酸化銀のアムモ二ア溶液にて酸化して脂肪酸となし殘䤣の $18 \mathrm{~g}$ : 上減壓蒸溜に附したりその成績次の如し

\begin{tabular}{|c|c|c|c|c|c|c|c|c|}
\hline 溜分 & $\begin{array}{l}\text { 溜出溫度 } \\
\left({ }^{\circ} \mathrm{C}\right)\end{array}$ & $\begin{array}{l}\text { 減 据 } \\
\text { (mm) }\end{array}$ & $\begin{array}{l}\text { 收億 } \\
(\mathrm{g})\end{array}$ & 分子量 & 熟子算 & $\begin{array}{l}\mathrm{C}_{n} \mathrm{H}_{2 n} \mathrm{O} \\
と し()\end{array}$ & $n_{1}^{2 n}$ & 凝 固 試 驗 \\
\hline (1) & $120-130$ & 25 & 1 & 151 & $\mathbf{C}_{10}$ & 156 & 1.4439 & 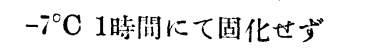 \\
\hline$(2)$ & $130-150$ & " & 5 & 182 & $\mathrm{C}_{12}$ & 184 & 1.4429 & " \\
\hline (3) & $150-170$ & " & 7 & 216 & $\mathrm{C}_{14}$ & 212 & 1.4468 & 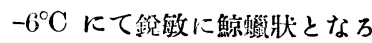 \\
\hline (4) & $170-190$ & " & 3 & 245 & $\mathrm{C}_{16}$ & 240 & 1.4459 & $5^{\circ} \mathrm{C}$ にて哂木䄕狀となる \\
\hline (5) & 殘 & " & 2 & - & & & - & - \\
\hline
\end{tabular}

上記實驗に於て分子量はベンゾール凝㸃降下法に低れしり

溜分（4）のセミカーバジンを作り酒精より再結晶やしめたるに融點 $93^{\circ} \mathrm{C}$ を示やりり

溜分（2）を元素分析したるに次の如し

\begin{tabular}{|c|c|c|c|c|c|}
\hline \multirow{2}{*}{ 試 料 $(\mathrm{g})$} & \multirow{2}{*}{ 水 $(\mathrm{g})$} & \multirow{2}{*}{ 荻 酸 $(\mathrm{g})$} & \multirow{2}{*}{$\mathrm{C} \%$} & \multirow{2}{*}{$\mathrm{H} \%$} & $\mathrm{C}_{12} \mathrm{H}_{24} \mathrm{O} \sigma$ 理馀數 \\
\hline & & & & & $\mathrm{C \%}$ \\
\hline 0.2243 & 0.2630 & $0.6+19$ & 78.04 & 13.12 & 78.18 \\
\hline
\end{tabular}

斯の如くして得たるアルデヒド類は正アルデヒドに比しその融默筧しく低くイソ化命物なりと考へらる即ち 』和正アルデヒドの性質を記せば次の如し

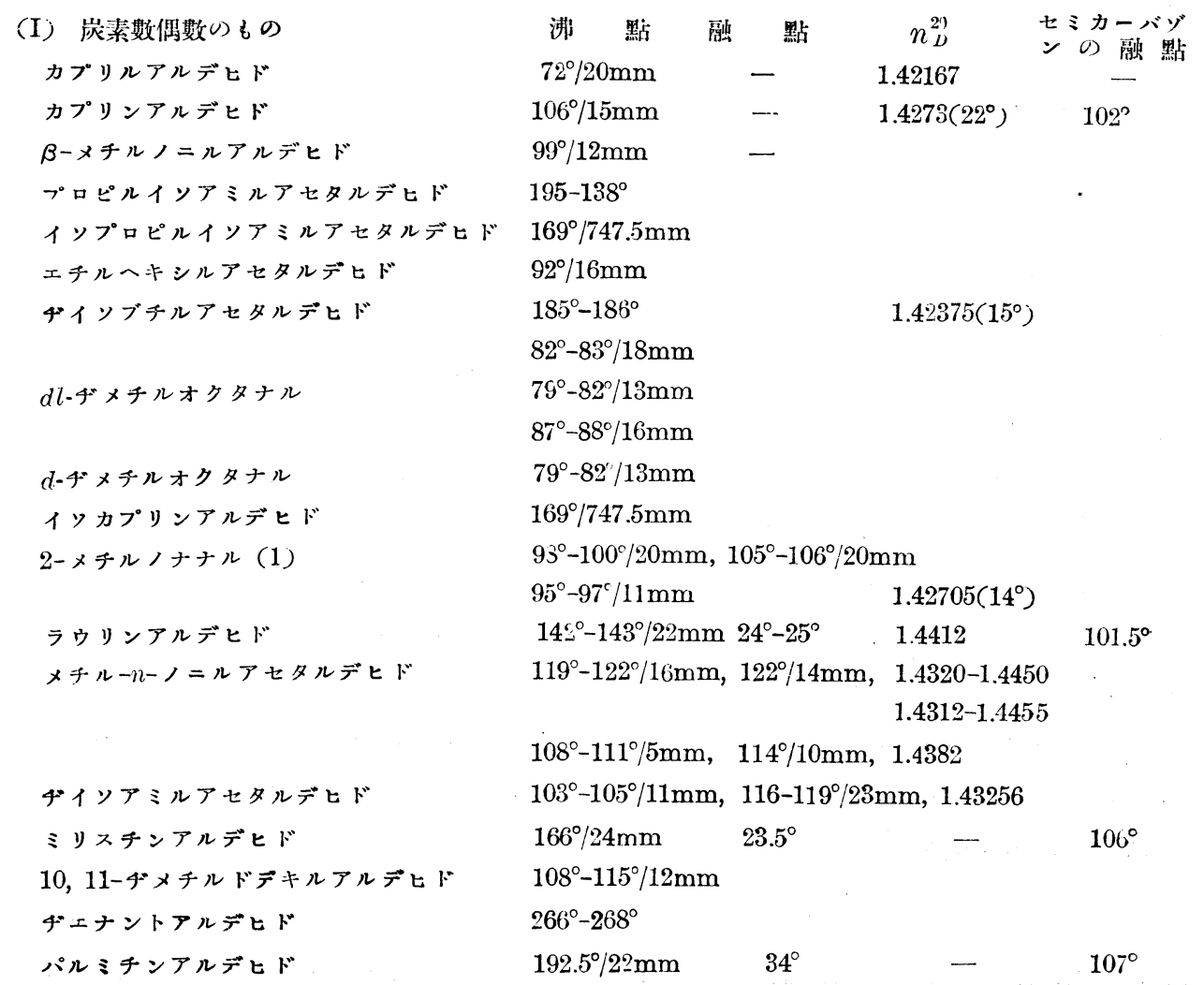


(II) 宸素數奇數のもの $n$ ーノ=ルアルデ七ド nーウンデキルアルデ七ド nートリデキルアルデヒド 及-メデルドデキルアルデ七ド ペンタデカナル
沸

$93.5^{\circ} / 23 \mathrm{~mm}$

$116^{\circ}-117^{\circ} / 18 \mathrm{~mm}$

$156^{\circ} / 23 \mathrm{~mm}$

$112^{\circ}-113^{\circ} / 12 \mathrm{~mm}$

$185^{\circ} / 25 \mathrm{~mm}$
融 點

$n_{D}^{20}$

$1.42417\left(18.5^{\circ}\right)$

$-4^{\circ}$

$14^{\circ}$

$24^{\circ}-25^{\circ}$
セミカーバゾ

$100^{\circ}$

若し得たるアルデヒドが不飽和基を有するならばとを直接沃素價の測定をなすときはアルデヒド基が JClに 依りて酸化を蒙る結果 $\mathrm{JCl}$ を過剩に消費する盧あり故に之等のアルデヒドを脂肪酸に變じて沃素價を湘定せ んと試みたりこのとき强烈なる酸化諯を用ふれば不飽和基が酸化破壞せらる〉虞ある故に酸化銀のアムモニア 溶液によりて酸化を行ひたり

$8 \mathrm{~g}$ の酳酸銀を $666 \mathrm{~g}$ の水に溶解し $14 \mathrm{~g}$ の $25 \%$ 节性曹達溶液を加へ更に $34 \mathrm{~g}$ のアムモニアを加へて生じた る酸化銀を溶解せしめ之に $4 \mathrm{~g}$ のアルデヒドを加へ湯浴上に 2.5 時間加溫し嚂酸アルコール溶液にて生成せる

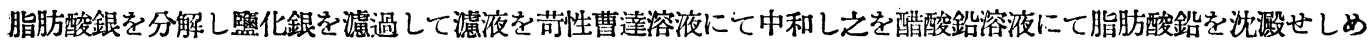
鉛監アルコール法 (Grün; Analyse d. Fette u. Wachse I, 221) に依りて固僼酸と液體酸とを分離せり

固㗐酸 $2.5 \mathrm{~g}$ をアルュールより再結晶せしめて次のものを得たり

\begin{tabular}{|c|c|c|c|c|c|c|}
\hline 第一回結晶 。 & 點 & $n \cdot \mathrm{C}_{n} \mathrm{H}$ & ${ }_{2} \mathrm{H}_{2}$ の融點 & 分子量 & \multicolumn{2}{|c|}{ 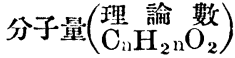 } \\
\hline I & $49^{\circ} \sim 50^{\circ} \mathrm{C}$ & $\mathrm{C}_{16}$ & $62.6^{\circ} \mathrm{C}$ & 一 & & \\
\hline II & $42^{\circ} \mathrm{C}$ & $\mathrm{C}_{15}$ & $53^{\circ}-54^{\circ} \mathrm{C}$ & 241 & $\mathrm{C}_{15}$ & 242 \\
\hline III & $33^{\circ} \sim 34^{\circ} \mathrm{C}$ & $\mathrm{C}_{14}$ & $53.8^{\circ} \mathrm{C}$ & 231 & $\mathrm{C}_{14}$ & 228 \\
\hline 第二包結晶 & （第一回結晶析 & 夜より) & & & & \\
\hline IV & $39^{\circ} \mathrm{C}$ & $\mathrm{C}_{14}$ & $53.8^{\circ} \mathrm{C}$ & 231 & $\mathrm{C}_{14}$ & 228 \\
\hline V & $29^{\circ}-30^{\circ} \mathrm{C}$ & " & " & 226 & " & " \\
\hline VI & $20^{\circ}-22^{\circ} \mathrm{C}$ & " & " & 222 & " & " \\
\hline
\end{tabular}

上記の分子量は $N / 10$ アルコール性菏性加里液によりて滴定し一監基酸として計算して得たり

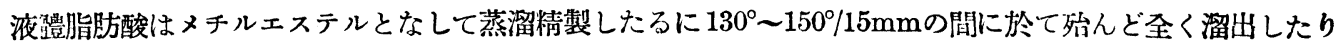
收量小なる故に各溜分に分たずして之を加水分解し無色の液澧酸 $1.4 \mathrm{~g}$ を得たり之を $N / 10$ アルコール性苛性 加里液にて同樣に滴定し分子量を測定して 191 を得たりこの夜體酸は $5^{\circ} \mathrm{C} に$ 於て結晶し始め $3^{\circ} \mathrm{C} に$ 於て流 動性を失ひ $-2^{\circ}$ に於ては全く凝固す脂肪酸の 理論分子量 $\mathrm{C}_{11} \mathrm{H}_{22} \mathrm{O}_{2}$ は $186, \mathrm{C}_{12} \mathrm{H}_{24} \mathrm{O}_{2}$ は 200 なり之に比較 するにこの液體酸は $\mathrm{C}_{11}$ 酸に近し然れどもアルデヒドの溜分より明かなる如く $\mathrm{C}_{10}, \mathrm{C}_{12}$ の混合酸と考へらる

この液體酸の沃素價 (ウィイス氏法) を測定せるに 27.0 を得たりこの值は $\mathrm{C}_{12} \mathrm{H}_{22} \mathrm{O}_{2} \mathrm{~F}_{1}$ の理論沃素價 129 なる數值に比して甚だ小なり依りてこの液體酸は殆んど飽和酸のみより成り從て原のアルデヒドも亦脂肪屬飽 和化合物より成り之に少量のオレフィン系脂肪屬化合物を含むものと考へらる

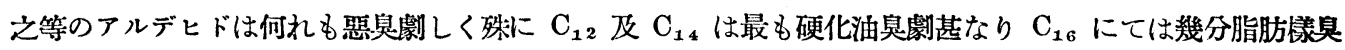
氣となりて刺激性を減ず刃之等のアルデヒドは眝藏中重合し易く $\mathrm{C}_{10}$ は殊に此性强く $\mathrm{C}_{16}$ は永く之を眝藏す れば固形無臭重合物を沈澱す 
硬化油を製する際の惡臭の主なる原因として認め得べきアルデヒド殊沈 $\mathrm{C}_{10^{-}}, \mathrm{C}_{12^{-}}, \mathrm{C}_{14^{-}}, \mathrm{C}_{16^{-}}$, 脂肪屬アルデ ヒドを分離せり之等のアルデヒドは主として飽和化合物と少量のオレフィン系化合物とより成り前に報告せる 硬化油製造の揮發性惡臭物より分離せる炭化水素、アルコール類と同樣に側顉を有する化合物なりと考へらる

（資生堂工場研究室）（昭和六年一月一四日受理）

\title{
石鹼中の遊離脂肪及び其の定量法の改瓦
}

\author{
川合 誠治 ・外池 力雄
}

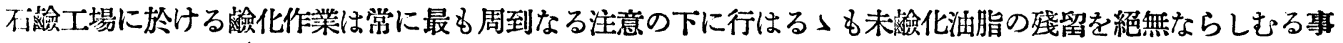

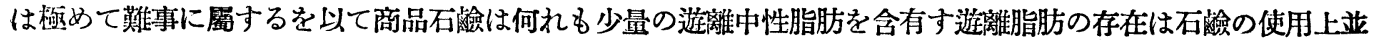
に䝪藏中に於て種々の不都合を招來するを以て其の含量は成る可く僅少ならざるべからず

不险中に於ける遊㒕脂肪の本質、性狀等に關しては未だ研究せられたる事なく又其の定量法の如きも區々に して互に相當なる結果を與へつっある有樣なり

余等はこれ等の不備の點に就て政究を開始し未だ所期の目的を達するに至らざれども石鐱中の遊離脂肪が原 料油脂に比して其の性狀を暴にせる事を明かにし得たり又遊㒕脂肪の定量法を改良しそれによりて市販化粧石 餄中の遊滩脂肪を定量したる結果從來發表せられたる數值に比して著しく小にして且つ比較的狹き範園に於て 一致せる事を知り得たるを以て以下に其の貫驗結果の大要を記載する事とせり

\section{（1） 化粧石瞼素地より遊離脂肪の抽出}

襝化工程中に於て微量に殘留する所謂遊㒕脂肪が原料油脂に比して其の性狀を異にするや否やを知らんと鿈 し通常の劣沸法によりて試製せる 2 種の機峨練素地より遊離脂肪を抽出試铪せり兩素地の製造に際して選べる 原料油脂の配合量及び乾燥素地の分析結果を示せば下の如し

油脂配 合量

\begin{tabular}{|c|c|c|c|c|}
\hline & \multicolumn{2}{|c|}{ 素地I } & \multicolumn{2}{|c|}{ 紧地II } \\
\hline & $\mathrm{kg}$ & $\%$ & $\mathrm{~kg}$ & $\%$ \\
\hline 脂 & 6484 & 79.7 & 4305 & 84.2 \\
\hline 㯝 子 油 & 1215 & 14.8 & 810 & 15.8 \\
\hline パーム油 & 450 & 5.5 & - & - \\
\hline
\end{tabular}

乾燥素地の分析表

化合脂肪酸

化合アルカリ

水分

遊踓アルカリ

遊㬨 脂 肪

不 鰫 化 物

食畋

グリセリン

\section{素 地 I}

$71.14 \%$

8.79

15.78

0.016

0.060

0.35

0.56

3.37
葲 地 II

$73.07 \%$

9.03

14.94

0.028

0.035

0.07

0.50

1.97

乾燥素地より得たる 混合脂肪酸 (遊㒕脂肪及び不 鹼化物拢き）の性質下の如し

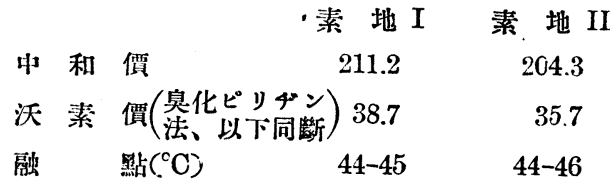

素地 I 几就ての實驗 遊離脂肪及び不畧化物を 抽出するにエーテルを使用せり素地 $50 \mathrm{~g}$ を熱湯に溶 解し適量のアルコールを加へて冷却せしめたる後こ れを分液漏斗に移しエーテル $300 \mathrm{cc}$ を加へてよく振

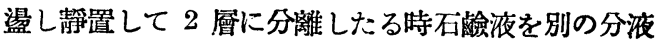
漏斗に拔き取り更にエーテル $300 \mathrm{cc}$ を加へて振盪せ りこの操作を反覆して素地 I $3 \mathrm{~kg}$ を處理せり抽出エ 一テル液は水洗し無水硫酸曹達にて脫水したる後エーテルを蒸溜せりフラスコに殘れる抽出物は遊離脂肪及び 不䍄化物以外に脂肪酸を夾雜せるを以てアルコールに溶解せしめ中和に要する量よりも稍過剩に酒情性苛性加 